\title{
OXYGEN ISOTOPE GEOCHEMISTRY OF A POTÁSSIO PORPHYRITIC CALC-ALKALIC COMPOSITE PLUTON: THE ITAPORANGA BATHOLITH, STATE OF PARAÍBA, NORTHEASTERN BRAZIL
}

\author{
GORKI MARIANO*, ALCIDES NÓBREGA SIAL* and NORMAN HERZ**
}

\begin{abstract}
RESUMO GEOQUÍMICA DE ISÓTOPOS DE OXIGÊNIO DE UMPLUTÃO POTÁSSICOCÁLCIO-ALCALINO COMPOSTO: O BATÓLITO DE ITAPORANGA, ESTADO DA PARAÍBA, NORDESTE DO BRASIL. O batólito de Itaporanga, composto, porfírítíco, cálcio-alcalino intrudiu o contato dos metassedimentos dos grupos Cachoeirinha-Salgueiro com os gnaisses do embasamento, no oeste da $\mathrm{Pa}$ raíba, nordeste do Brasil. O elevado grau de interação entre rochas máficas (dioritos potássicos) com rochas félsicas porfirfticas (quartzo monzonito a granito), originando rochas híbridas (monzonito e granodiorito), desenvolveram estruturas migmatfticas (estromátíca e agmática), sugerindo coexistência e mistura de magmas como um processo principal durante a evolução do plutão. Análises de isòtopos de oxigênio foram obtidas a partir de rocha total, e minerais separados para os diferentes tipos litológicos do plutão. Devido à sua resistência ao intemperismo e reduzida troca isotópica, o quartzo foi escolhido para comparar os valores de

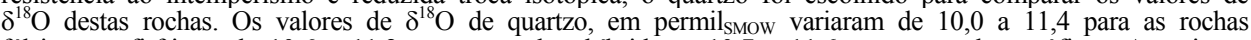
félsicas porfirfticas, de 10,6 a 11,2 para as rochas híbridas e 10,7 a 11,6 para as rochas máficas. A variação dos valores de $\delta^{18} \mathrm{O}$ para todos os tipos litológicos do plutão está em torno de 2 permil tensa troca isotópica provavelmente controlada por mistura mecânica e química de "mushes". Duas análises de isòtopos de oxigênio em rochas encaixantes (filito e biotita xisto) coletadas aproximadamente $1 \mathrm{~km}$ a sul do batólito mostraram $\delta^{18} \mathrm{O}$ em rocha total com 14,9 permilsMow e 14,7 permilsMOW respectivamente. Comparação entoe estes valores com os valores obtidos para as rochas que constituem o batólito de Itaporanga sugere reduzida assimilação de material crustal. $\mathrm{O}$ geotermômetro baseado no par isotópico quartzo-biotita convertido para quartzo-magnetita mostrou temperaturas entre $507^{\circ} \mathrm{C}$ e $677^{\circ} \mathrm{C}$, com a maioria delas entre $507^{\circ}$ e $584 \mathrm{C}$. Essas temperaturas podem não representar a de cristalização nem a de equilíbrio para os minerais estudados, mas possivelmente representam o intervalo de intensas trocas isotópicas em temperaturas subsolidus. Geobarometria, baseada no teor de Al de anfibòlio cálcico (ferroedenita a edenita), sugere que a cristalização do plutão ocorreu a pressão de aproximadamente $5, \mathrm{O}$ kbar $\pm 1,0 \mathrm{kbar}$, correspondendo ao intervalo de profundidade de $16 \mathrm{~km}$ a $20 \mathrm{~km}$.
\end{abstract}

Palavras-chaves: Isòtopos de oxigênio, geotermometria, geobarometria, Estado da Paraíba, Brasil.

\begin{abstract}
The composite porphyritic, potassic calc-alkaline Itaporanga batholith was intruded between the metasediments of the Cachoeirinha-Salgueiro groups and the gneisses of the basement, in the western portion of the State of Paraíba, Northeastern Brazil. The close interaction of mafic (potassium diorite) with felsic porphyritic rocks (quartz monzonite to granite) forming hybrid ones (monzonite to granodiorite) developed migmatite-like structures (stromatic and, less often, agmatic) suggesting coexistence and mixing of magmas as a major process during the evolution of this pluton. Quartz, known for its resistance to wheatering and subsequent oxygen isotope exchange, was used to compare the $\delta^{18} \mathrm{O}$ values among these rocks. Quartz $\delta^{18} \mathrm{O}$ values, in permil $\mathrm{SMO}_{\mathrm{S} \text {, }}$,Vary from 10.0 to 11.4 from the felsic pophyritic rocks, from 10.6 to 11.2 for the hybrid rocks, and from 10.7 to 11.6 for the mafic ones. Thus the oxygen isotope compositions for all lithologies in the pluton vary within 2 permil suggesting oxygen isotope exchange probably controlled by mechanical and chemical mixing of magmas. Two country rocks, a biotite schist and a phyllite collected approximately $1 \mathrm{~km}$ south of the Itaporanga batholith, had whole rock $\delta^{18} \mathrm{O}$ values of 14.9 permil for these rocks and for the rocks which compose the Itaporanga pluton indicated reduced country rock assimilation during its evolution. The oxygen isotope geothermometry based upon the coexistence of quartz and biotite converted into the quartz-magnetite pair gave temperatures from $507^{\circ} \mathrm{C}$ to $677^{\circ} \mathrm{C}$ most of them between $507^{\circ} \mathrm{C}$ and $584^{\circ} \mathrm{C}$. These temperatures may not represent neither crystallization nor closure temperatures for the mineral studied, but the interval at which subsolidus isotope exchange took place. Geobarometry based on Al content of calcic amphibole (ferroedenite to edenite) gave crystallization pressures around $5.0 \pm 1 \mathrm{kbar}$, corresponding to a depth of emplacement of $16 \mathrm{~km}$ to $20 \mathrm{~km}$.
\end{abstract}

Keywords: Oxygen isotopes, geothermometry, geobarometry, State of Paraíba, Brazil.

INTRODUCTION The principal purpose of this work is to evaluate the approximate temperature and pressure of emplacement of the Itaporanga batholith, a representative of the coarse grained porphyritic granitoids of Northeastern Brazil. This composite, diapirically emplaced pluton, with an area of approximately $200 \mathrm{~km}^{2}$, located north of the town of Itaporanga, in the western portion of the state of Paraíba (Fig. 1 ), represented a unique opportunity to study mixing of magmas in the root zone of a diapir.

The Itaporanga batholith shows a compositional gradation from potassium diorite, monzodiorite, quartz monzonite, granodiorite to granite.

Field evidence suggests mechanical interaction between potassium diorite and granite magmas as responsible for the lithologic types which compose the pluton. Important field evidences favoring mixing of magmas are: a. igneous texture and mineralogy of the mafic enclaves (potassium diorite); $b$. presence of pillow-like structures, indicating quenching of the hotter mafic magma in contact with the felsic cooler one, characterized by abundant stubby and acicular apatite; c. widespread distribution of stromatic and, less often, agmatic structures.

During field work three major lithologic domains were identified: a. Hybrid zone - characterized by abundant stromatic structures, where felsic porphyritic rocks (quartz monzonite to granite) are found side by side with K-dioritic bands (10 $\mathrm{cm}$ to $50 \mathrm{~cm}$ wide); b. Porphyritic zone - composed essentially of coarsely porphyritic quartz monzonite to granite

\footnotetext{
* Centro de Tecnologia, Departamento de Geologia, Universidade Federal de Pernambuco, Rua Acadêmico Hélio Ramos, s/nº, 4- andar, Cidade Universitária, CEP 50741, Recife, PE, Brasil

** Department of Geology, University of Georgia, 30602 Athens, GA, Estados Unidos
} 
with variable proportion of potassium diorite mafic enclaves and c. Commingling zone where potassium diorite and felsic porphyritic rocks can be individualized at outcrop scale. Detailed petrography of the rocks composing the Itaporanga pluton is found in Mariano (1989).

Previous work in this area was done by Sial $(1984,1986)$ who did oxygen isotope analyses of a few whole rock and mineral separates (quartz and feldspars) from the Itaporanga batholith and other granitoids in Northeastern Brazil. He identified regional isotopic signatures. Oxygen isotope data in this paper is used as geothermometer. It also indicates reduced country rock assimilation and meteoric water interaction (during cooling) as major petrogenetic processes, and suggests intense isotopic exchange among the lithologic types in the pluton.

The results of microprobe analyses of calcic amphibole suggest reequilibrium between enclaves (potassium diorite) and felsic porphyritic rocks (quartz monzonite to granite) and are used to compare the chemistry of the igneous mafic enclaves (potassium diorite) with a potassium dioritic stock located east of the Itaporanga body. The Al content of calcic amphibole is used to infer the approximate depth of emplacement or last upward migration of the batholith.

\section{Stable Isotopes Introduction Oxygen isotope} studies in granitic rocks can be used to evaluate petrogenetic processes such as country rock assimilation (James 1981, 1982, Taylor 1980), mixing of magmas of different oxygen isotope signatures, slow cooling through crystallization (Giletti 1986), and rock-water interaction during cooling (Taylor 1968, 1971, Taylor \& Forester 1979). Oxygen isotopic ratios also serve as a tracer of the source material of granitic rocks: if they are formed by an anatectic melt of metasediments, their $\delta^{18} \mathrm{O}$ values will be several orders of magnitude higher than if they were formed from igneous sources (O'Nea et al 1977, Masi et al. 1981, Shieh \& Schwarcz 1974, Wenner 1981).

The use of oxygen isotopes as a geothermometer for igneous systems (especially for the plutonic environment) is rather complex since several syn-and post-crystallization processes (magma mixing, assimilation, hydrothermal alteration, metamorphism, meteoric water interaction) may promote oxygen isotope fractionation or reequilibrium. The temperature determined may be that reached during the related event and not the original temperature of crystallization.

Giletti (1986) discussed the usefulness of oxygen isotopic temperatures. Using an idealized simple rock composed of hornblende, feldspar and quartz, he showed that even with slow cooling and no other interfering processes, a certain number of parameters are still needed to correctly determine the temperature of crystallization including: activation energy

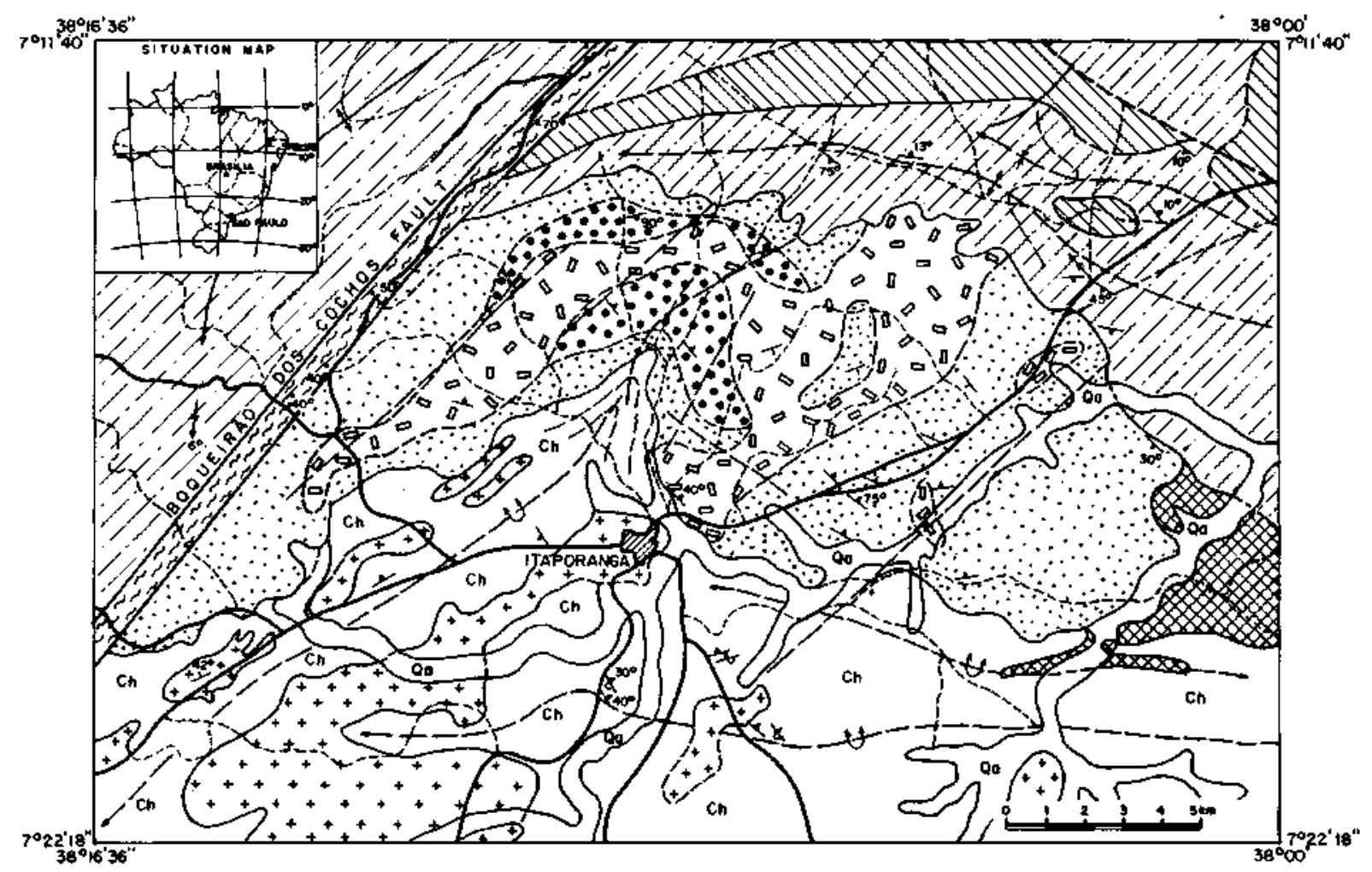

LEGEND

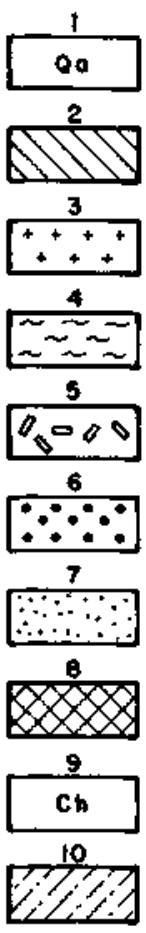

Figure 1 - Geologic map of the Itaporanga batholith modified from Silva Filho (1985): 1. Quaternary alluvial deposits; 2. Biotite granodiorite; 3. Conceição-type granitoids; 4. Mylonitic rocks; 5. Itaporanga batholith - porphyritic zone - granite to quartz monzonite, with potassium feldspar megacrysts up to $10 \mathrm{~cm}$ long; 6. Itaporanga batholith - commingling zone - mafic (potassium diorite) - felsic (porphyritic granite to quartz monzonite) individualized at outcrop scale; 7. Itaporanga batholith - hybrid zone intense degree of interaction between monzonitic to monzodioritic and granitic magmas; 8. potassium diorite stock east of the Itaporanga pluton; 9. Cachoeirinha Group (phyttites, schists, etc.); 10. Serido Group (amphibolite, gneiss, etc) Figura 1 - Mapa geológico do Batólito Itaporanga, modificado de Silva Filho (1985): 1. Aluviões quaternários; 2. Biotita granodiorito; 3. Granitóides do tipo Conceição; 4. Rochas miloníticas; 5. Batólito Itaporanga - zona porfírftíca - granito a quartzo monzonito, com megacristais de feldspato potássico de até $10 \mathrm{~cm} ; \mathbf{6}$. Batólito Itapoanga - zona de mistura máfica (diorito potássico) - félsica (granito porfirftico a quartzo monzonito) individualizado em escala de afloramento; 7. Batólito Itaporanga - zona híbrida - intenso grau de interação entre os magmas monzonftico a monzodiorítico e granítico; 8. Stock de diorito potássico a leste do pluton de Itaporanga; 9. Grupo Cachoeirinha (fílitos, xistos etc); 10. Grupo Seridó (anfibolito, gnaisse etc) 
for oxygen diffusion in the mineral, diffusional anisotropy, pre-exponeritial factor in oxygen diffusion (Arrhenial relation), mineral grain size, and rate of cooling. Even if all these parameters are known the temperature obtained may still not be the crystallization temperature for that mineral.

The main problem with his model is its restricted application to post-tectonic plutons that do not interact with the country rocks and cool slowly. Those constraints restrict the applicability of the method and illustrate how difficult it is to apply oxygen isotope geothermometry to igneous systems. The only igneous rocks capable of freezing crystallization temperature for the different mineral phases are rapidly cooled (quenched) volcanic rocks (Anderson et al. 1971).

Experimental Procedures Mineral separation was made essentially by hand picking except for pre-concentration of the felsic portion of some rocks with the Frantz isodynamic separator. Quartz grains were washed in cold HF for five minutes then rinsed with tap water and acetone. Biotite and feldspar were washed with tap water and placed in an ultrasonic cleaner for a few minutes and rinsed with acetone. The purity of mineral separates is better than $95 \%$.

Whole rock analysis were performed on rock powder crushed to $<200$ mesh in an agate or a porcelain ball mill. Samples analysed were weighed 12 hours before loading and placed in an oven at a temperature of $120^{\circ} \mathrm{C}$.

Oxygen was extracted from silicates by reaction with fluorine (Fa) at $580^{\circ} \mathrm{C}-590^{\circ} \mathrm{C}$ for a period of 12 hours. The $\mathrm{CO}_{2}$ used for mass spectrometry was produced by oxygen combustion with a resistance-heated carbon rod as described by Taylor \& Epstein (1962a,b). For each set of mineral separates or whole rocks analyzed, the Caltech rose quartz was run as an internal standard.

Mass spectrometry analyses were performed on $\mathrm{CO}_{2}$ gas using a triple collector, dual gas inlet Finnigan Mat Delta mass spectrometer. The precision of mass spectrometry, including extraction procedures, was approximately 0.1 permil.

Analysis were performed al the University of Georgia, Department of Geology, Riverbend Research Laboratories.

Oxygen Isotope Data Oxygen isotope data for the Itaporanga batholith include 24 quartz, nine biotite, seven potassium feldspar and 14 whole rock analyses (Tab. 1). Two additional whole rock analyses were conducted for the country rock metasediments.

Quartz was the mineral selected for comparison between the different lithologic types in the Itaporanga batholith because of its resistance to post-crystallization exchange and alteration. The $\delta^{18} \mathrm{O}$ obtained for quartz of the felsic porphyritic phase (quartz monzonite to granite) ranged from 10.0 permil to 11.2 permil, averaging 10.8 permil, in 15 samples distributed throughout the batholith. Four $\delta^{18} \mathrm{O}$ values of quartz determined for the mafic rocks (potassium diorite) varied from 10.7 permil to 11.3 permil, with an average of 10.9 permil. One mafic enclave with sharp contacts with the felsic' porphyritic rock had $\delta^{18} \mathrm{O}$ for quartz of 11.6 permil $(173 \mathrm{E}$, Tab. 1). Two quartz samples from hybrid rocks, formed by interaction between felsic and mafic magmas, had $\delta^{18} \mathrm{O}$ values of 10.6 permil and 11.6 permil $(1 \mathrm{H}, 2 \mathrm{H}$, Tab. 1$)$.

Two pairs of samples representing the porphyritic felsic and the hybrid components (IP, $1 \mathrm{H}$ and $2 \mathrm{P}, 2 \mathrm{H}$, Tab. 1) showed $\delta^{18} \mathrm{O}$ differences for quartz of 0.2 permil demonstrating that oxygen isotope exchange took place between the different lithologies.

There is no systematic evidence that the mafic magma had a lower $\delta^{18} \mathrm{O}$. Oxygen isotope values obtained for quartz for mafic and felsic rocks, sometimes within the same outcrop, actually showed the former to be $\delta^{18} \mathrm{O}$ enriched $(157,157 \mathrm{M}$, Tab. 1).

The $\delta^{18} \mathrm{O}$ values obtained for whole rock powders vary from 7.7 permil $(145 \mathrm{M})$ to 9.2 permil $(161 \mathrm{H})$ (Tab. 1). These values are similar to those obtained through the following empirical relation:

$\delta^{18} \mathrm{O}$ whole rock $=\delta^{18} \mathrm{O}$ quartz - 1.2 (Tab. 1).

Taylor (1971) stated that secondary alteration such as chloritization of biotites, serialization of plagioclase and clouding of alkali-feldspar could seriously affect $\delta^{18} \mathrm{O}$ whole rock values. The whole $\delta^{18} \mathrm{O}$ values obtained for the Itaporanga pluton seem to represent magmatic values, suggesting reduced intensity of the post-crystallization alteration processes.

Two country rocks, a biotite schist witft $\delta^{18} \mathrm{O}=14.9$ permil and a phyllite with $\delta^{18} \mathrm{O}=14.7$ permil were collected approximately $1 \mathrm{~km}$ south of the Itaporanga batholith. Comparisons between the $\delta^{18} \mathrm{O}$ values obtained for these rocks with the rocks which compose the Itaporanga pluton suggest that country rock assimilation was not important during the petrogenetic evolution of the pluton, which showed a strong homogeneity of oxygen isotope data for whole rock and mineral separates with average rim to core variation whithin 1 permil.

Table 1 shows whole rock $\delta^{18} \mathrm{O}$ of 7.7 permil for a mafic $(145 \mathrm{M})$ and 8.5 permil for a hybrid rock $(145 \mathrm{H})$ within the same outcrop close to a major fault zone (Boqueirão dos Cochos fault). These low values may reflect a 1 permil depletion due to interaction with water near the fault zone.

A potassium diorite body located to the east of the Itaporanga pluton (117-DI, Tab. 1) has $\delta^{18} \mathrm{O}$ of 10.8 permil, which is within 1 permil difference of the mafic portions inside the pluton. This small potassium diorite body shows mineralogy, major and trace element chemistry identical to the Itaporanga pluton igneous mafic enclaves.

The homogeneity of the $\delta^{18} \mathrm{O}$ of the Itaporanga batholith and its syn-tectonic emplacement on the Brasiliano cycle suggest that isotopic exchange and equilibrium may have been reached during this period. Otherwise it would be very difficult to explain such homogeneous behavior in $200 \mathrm{~km}^{2}$ batholith, which is deformed and shows areas of intense interaction between felsic (quartz monzonite to granite) and mafic (potassium diorite) magmas.

Tests for oxygen isotopic equilibrium among the Itaporanga batholith samples is show in figures 2 and 3 . Figure 2 shows $\delta^{18} \mathrm{O}$ for mineral separates and whole rock. This diagram evidences oxygen isotope equilibrium, with quartz more enriched in the heavy isotope and biotite the most depleted. Figure 3 shows a near linear relationship between Qz-Bi versus $\Delta$ Qz-Kf also suggesting oxygen isotope equilibrium (Deines 1977).

Oxygen Isotope Geothermometry Table 2 shows $\delta^{18} \mathrm{O}$ analyses for nine pairs of quartz-biotite and seven pairs of quartz-potassium feldspar. These rocks are geographycally well distributed within the batholith, also representing the more common lithologic type (felsic porphyritic monzonite to granite). The oxygen isotope geothermometer quartz-biotite pair was converted into the quartz-magnetite pair, based on the relation $\mathrm{A} \mathrm{Qz}-\mathrm{Bi}=.59 \mathrm{x} \mathrm{Qz}-\mathrm{Mt}$ suggested by Taylor (1968) and Shieh \& Schwarcz (1974) The A QuartzMagnetite was obtained from the A Quartz-Water and A Magnetite-Water equations of Bottinga \& Javoy (1973) for the temperature range of $500^{\circ} \mathrm{C}$ to $800^{\circ} \mathrm{C}$ which fimit its use to differences in the Qz-Mt pair within the interval 4.8 permil -9.3 permil.

The temperature obtained with the Qz-Mt pair ranged from $507^{\circ} \mathrm{C}$ to $677^{\circ} \mathrm{C}$ with most between $507^{\circ} \mathrm{C}$ and $584^{\circ} \mathrm{C}$ (Tab. 2).

The oxygen isotope geothermometer based on the Qz-Kf pair was obtained from Bottinga \& Javoy (1973) equations for the system A Qz-Water and AK-feld-Water for the temperature range of $500^{\circ} \mathrm{C}$ to $800^{\circ} \mathrm{C}$, restricting its use to 
Table 1 - Oxygen isotope data for the Itaporanga batholith Tabela 1 - Dados de isótopo de oxigênio para o Batólito Itaporanga

\begin{tabular}{|c|c|c|c|c|c|c|}
\hline \multirow{2}{*}{$\begin{array}{l}\text { Sample } \\
\text { Number }\end{array}$} & \multicolumn{3}{|c|}{ Mineral } & \multirow[t]{2}{*}{ W.R. ${ }^{\dagger}$} & \multirow[t]{2}{*}{ W.R.2 2} & \multirow[t]{2}{*}{ Diff. } \\
\hline & Quintz & K-Felds. & Biotite & & & \\
\hline \multicolumn{7}{|c|}{ Felsie Porphyritte (Quartz Momzonite to Granite) } \\
\hline TTA 1P & 10.4 & 9.3 & 6.8 & 9.2 & 8,5 & .7 \\
\hline ITA 2P & 11,0 & & & 9.8 & 8.4 & 1,3 \\
\hline ITA 10 & 10,9 & 9.1 & 5.8 & 9.7 & & \\
\hline ITA 80 & 11,2 & 9.3 & 5.8 & 10,0 & & \\
\hline ITA 91 & 11.0 & 9.7 & 6.2 & 9.8 & & \\
\hline ITA 101 & 11.4 & 9.7 & 6.4 & 10.2 & & \\
\hline ITA 115 & 10,0 & & & 8.8 & & \\
\hline ITA 128 & 11.1 & & & 9.9 & & \\
\hline ITA 131 & 10,9 & & & 9.7 & & \\
\hline ITA 148 & 10,2 & & 5.7 & 9.0 & & \\
\hline ITA 153 & 11.2 & 9.6 & 6.0 & 10.0 & & \\
\hline ITA 157 & 10,8 & & & 9,6 & & \\
\hline ITA 163 & & & & $9.6^{*}$ & 8.9 & .7 \\
\hline ITA 165 & 10.7 & & & 9.5 & & \\
\hline IrA 167 & 11.1 & & 5,3 & 9.9 & & \\
\hline ITA 178 & 10.7 & & & 9,5 & & \\
\hline ITA 189 & & & & 9.6 & 7.8 & 1.8 \\
\hline \multicolumn{7}{|c|}{ Hybrid (Monzonite to Granodiorite) } \\
\hline ITA $1 \mathrm{H}$ & 10,6 & 9.3 & 5.7 & 9.4 & 8.9 & .5 \\
\hline ITA 2H & 11.2 & & & 10.4 & & \\
\hline ITA 142H & & & & $9.9 *$ & 8.5 & 1.4 \\
\hline ITA 145H & & & & $9.9^{*}$ & 8.5 & 1.4 \\
\hline TTA 161H & & & & $9,9 *$ & 9.2 & .7 \\
\hline ITA 169H & & & & $9.9 *$ & 8.2 & \\
\hline
\end{tabular}

\begin{tabular}{llcccc}
\hline Manc (Monzodlorite to Diante) & & & \\
\hline ITA 1M & & $19.0^{*}$ & 7.5 & 2.5 \\
ITA 20M & 10.9 & 9.7 & 8.2 & 1.4 \\
ITA 131M & 11.3 & 10.1 & & \\
TTA 137M & & $10.0^{*}$ & 8.2 & 1.8 \\
ITA 145M & & $10.0^{*}$ & 7.7 & 2.3 \\
ITA 157M & 11.3 & 10.1 & & \\
ITA 161M & & $10.0^{*}$ & 8.1 & 1.2 \\
ITA 165M & 10.7 & 9.5 & & \\
ITA 173E & 11.6 & 10.4 & & \\
ITA117DI & 10.8 & 9.6 & & \\
\hline
\end{tabular}

1 - Whole rock data obtained from the following relationship $\delta 18 \mathrm{O}_{\mathrm{WR}}=\delta^{18} \mathrm{O}_{\mathrm{QZ}}-1.2 *$ Average $\delta^{18} \mathrm{O}_{\mathrm{QZ}}$ use to calculate $\delta^{18} \mathrm{OwR}$. 2 - Whole rock determined through oxygen isotope analysis

$117 \mathrm{DI}$ - potassium diorite pluton emplaced at the eastern contact of the Itaporanga batholith with the CSF metasediments.

$20 \mathrm{M}$ - potassium diorite in pillow-like structure; $1 \mathrm{M}, 145 \mathrm{M}, 161 \mathrm{M}$ $\mathrm{K}$-diorite as mafic layers in migmatite-like rock; 131-M, 157M, 165M, $173 \mathrm{E}$ - potassium diorite mafic enclaves; $173 \mathrm{M}$ - potassium diorite patch.

quartz-potassium feldspar differences between 0.8 permil and 1.6 permil. $\Delta \mathrm{Qz}-\mathrm{Kf}$ pairs with greater permil differences were not taken into consideration for temperature estimates. The temperatures obtained for the Qz-Qf geothermometer betweem $589^{\circ} \mathrm{C}$ and $683^{\circ} \mathrm{C}$ ( Tab. 2) are approximately $30^{\circ} \mathrm{C}$ higher than those obtained for Qz-Mt.

The temperatures obtained by oxygen isotope geothermometry were within the interval $507^{\circ} \mathrm{C}-677^{\circ} \mathrm{C}$ and may not represent neither crystallization nor closure

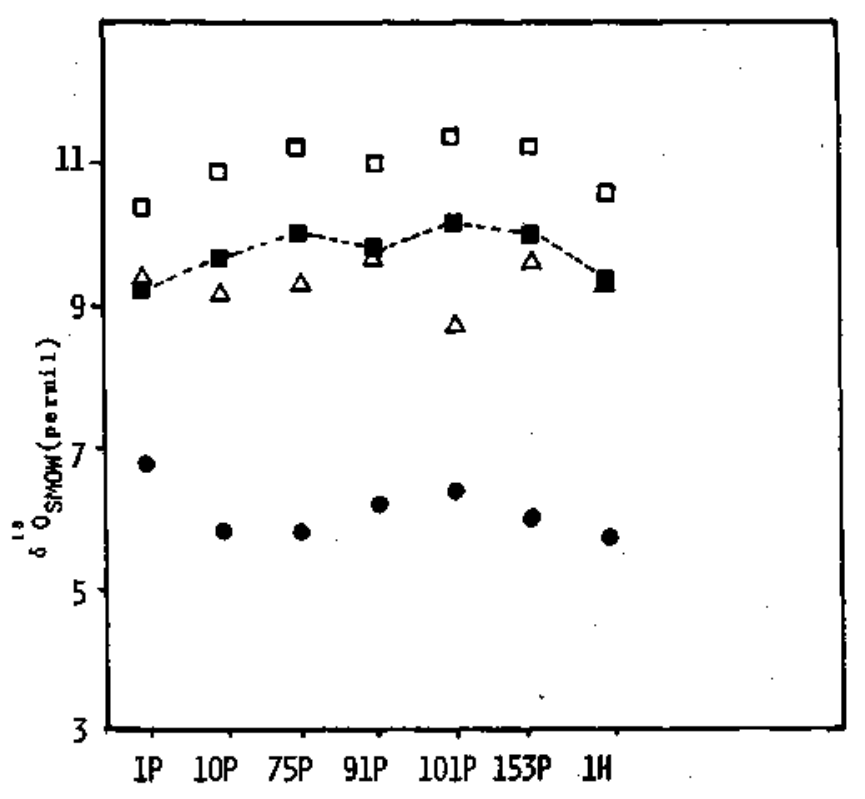

Figure $2-8^{18} \mathrm{o} / \mathrm{8}^{16} \mathrm{O}$ whole rock and mineral separates diagram of the Itaporanga batholith. Symbols are as follows (D) whole rock, ( $\square$ ) quartz, (O) biotite, and ( $\Delta) K$-feldspar. $I P, I O P$... are samples references

Figura $2-$ Diagrama ${ }^{18} \mathrm{O} / 8^{16} \mathrm{O}$ parn rochs total e minerais indivituais para o Batolito de Itaporanga, Os sfmbolos sfor (D) rocha total, ( $\square$ ) quartzo, (O) biotita e $(\Delta)$ feldspato potítsico

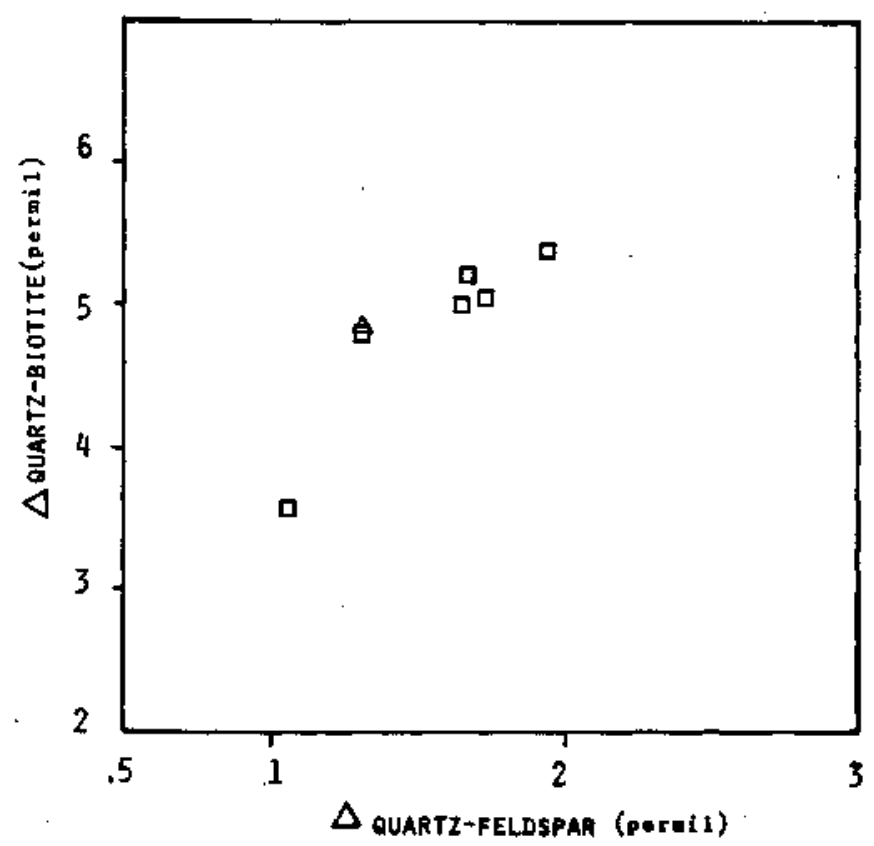

Figure 3 - Plot of axygen isotope mineral pairs ( $\triangle$ quartzbiotile versus $\Delta$ quartz-potassiton feldspar) for the ltaporanga batholith. ( $\square$ ) Felsic porphyritic quartz monzonite to granite ( $\Delta$ ) hybrid - porphyritic monzonite to granadiorite. Observe the near linear distribution suggesting equilbrivm anong mineral triplets

Figura 3 - Grffico dos istopoe de oxigtilo para parte de minerais ( $\Delta$ quartzo-biotita versas $\Delta$ quartzo-feldapato potistoo) para o Batolito Itaporanga. ([D) Felsico - quertzo monzonito porfifition a granito, $(\Delta)$ hfbrido - monzonito porfuftion a granodiorito, Obverve-se a distribuiçso linear aproximsda sugerindo equilforio entre os tro mineraits 
temperatures for the minerals studied, but the temperature interval at which subsolidus isotopic exchange last took place. The presence of sillimanite in the country rocks (sillimanite biotite schists) to the south and sillimanite + garnet (garnet biotite schists and gneisses) to the north of batholith suggests a metamorphic temperature between $600^{\circ} \mathrm{C}$ and $700^{\circ} \mathrm{C}$ corresponding to a pressure of approximately $4 \mathrm{kbar}-7 \mathrm{kbar}$. Pressures determined through Al content of calcic amphibole are around $5 \mathrm{kbar} \pm 1 \mathrm{kbar}$.

Table 2 - Oxygen isotope geothermometry for the Itaporanga bathouth

Tabela 2 - Geotermometria de isótopos de oxigênio para o Batdlito Itaporanga

\begin{tabular}{|c|c|c|c|c|c|}
\hline $\begin{array}{l}\text { Semple } \\
\text { Number }\end{array}$ & $\Delta_{\text {QZ-KF }}$ & $\Delta_{\alpha z-\mathrm{B}}$ & $\Delta_{\text {OZ-MT }}$ & Temp. & ${ }^{\circ} \mathrm{C}$ \\
\hline
\end{tabular}

Felsic Porphiritic (Quartz Mouzonite to Granlte)

\begin{tabular}{|c|c|c|c|c|c|}
\hline & & & & & 1 \\
\hline ITA 1P & 1.1 & 3,6 & 6,1 & 683 & 677 \\
\hline ITA 10 & $1,8^{*}$ & 5.1 & 8.6 & & 531 \\
\hline ITA 80 & $1,9^{*}$ & 5,4 & 9,1 & & 509 \\
\hline TTA 91 & 1.3 & 4.8 & 8.1 & 590 & 556 \\
\hline ITA 10t & $1.7^{*}$ & 5,0 & 8.5 & & 531 \\
\hline TTA 148 & & 4,5 & 7.6 & & 583 \\
\hline TTA 153 & $1.6^{*}$ & 5.2 & 8,8 & & 522 \\
\hline ITA 167 & & 5.8 & $9.8^{*}$ & & \\
\hline
\end{tabular}

Hybrid (Monzonite to Grenodiorite)

\begin{tabular}{llllll}
\hline ITA 1H & 1.3 & 4.8 & 8.2 & 587 & 550 \\
\hline
\end{tabular}

1 - Temperature obthined by the Quartz-K-feldspar pair, wing

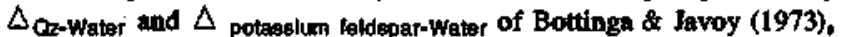
for the temperature range of $500-800^{\circ} \mathrm{C}$.

$\Delta_{\text {OZ-K.telds }}=0,97\left(10^{6} \times T^{-2}\right)$

2 - Temperiture obtined by the Quartz-Magnetite peir, uing $\Delta_{\mathrm{OZ}}$ water and $\Delta_{\text {Mt-Wamr }}$ of Bottinga \& Javoy (1973) for the temperature range of $500-800^{\circ} \mathrm{C}$.

$\Delta_{\text {Oz-Mt }}=5.57\left(10^{6} \times T^{-2}\right)$

* Difference in inotopic pair is ontside the range of tempentare at whlch the geothermomedry equation was calibrated. Those values were not used for temperature determination.

** $\Delta_{\mathrm{QZ}-\text { Ht }}$ obtainod from the followheg relationchip $\Delta_{\mathrm{OZ}-\mathrm{Bi}}=0.59$ $\Delta_{\text {Qz-in }}$ (Taylor, 1968 and Shied \& Schwerez, 1973)

AMPHIBOLE GEOBAROMETRY The Al content of calcic amphibole was proposed as a pressure indicator by Hammarstron \& Zen (1983, 1985 and 1986). They suggested the use of total aluminum in calcic amphibole as a geobarometer based on an empirical equation derived by a linear regression on an $\mathrm{Al}^{1}$ versus $\mathrm{Al}_{\mathrm{T}}$ plot for calc-alkaline rocks with amphibole crystallized at pressures from 2 to 8 kbar. Their equation has an error of ${ }^{ \pm} 3$ kbar which restricts its application to relatively high pressures ( $>6$ kbar).

Hollister et al. (1987) suggested new values for the Hammarstron \& Zen (1986) equation to fill the gap for calc-alkaline plutons emplaced at intermediate pressures. Their .equation was derived by calibration with calc-alccaline plutons whose emplacement pressures were determined from metamorphic mineral assemblages in country rocks.

In this work the amphibole geobarometry equation suggested by Hollister et al. (1987) is used because of its better fit for the intermediate pressure range and also for its reduced error ( \pm 1 kbar).

Microprobe analysis of amphibole of the Itaporanga pluton were made for $\mathrm{Si}, \mathrm{Al}, \mathrm{Fe}$ (total), $\mathrm{Mg}, \mathrm{Mn}, \mathrm{Ti}, \mathrm{Na}, \mathrm{K}$, and $\mathrm{Ca}$. An average of two points in the rim and one point in the core of each crystal were analysed. All amphiboles used for pressure determination were associated with quartz, potassium feldspar $\left(\mathrm{Or}_{86 \cdot \mathrm{go}_{0}}\right)$, plagioclase $\left(\mathrm{An}_{19-24}\right)$, biotite and titanite. Their compositions vary from ferroedenite to edenite (Leake 1978) with total iron $\left(\mathrm{FeO}_{\mathrm{t}}\right)$ content up to $24 \mathrm{wt}$ \% The small percentage of iron oxides, occasionally occuring as trace amounts, and the high iron content of amphiboles suggest low to intermediate $\mathrm{fO}_{2}$. The rim and core of the amphiboles show similar compositions, but only the rim analyses were used for pressure determination because this portion of the crystal most likely crystallized in equilibrium with the other mineral phases. The pressure obtained for the Itaporanga pluton was whithin $5.0 \pm$ kbar (Tab. 3) which corresponds to a depth interval of $16 \mathrm{~km}$ to $20 \mathrm{~km}$. Using the oxygen isotope geothermometry temperature $\left(550^{\circ} \mathrm{C}\right)$ this depth is consistent with a geothermal gradient of approximately $30^{\circ} \mathrm{C} / \mathrm{km}$, following cooling and crystallization of the pluton.

Table 3 - Representative microprobe analysis of amphibole Tabela 3 - Análise representativa de microssonda eletrônica em anfibólios

\begin{tabular}{|c|c|c|c|c|c|c|c|c|c|c|c|}
\hline \multirow[b]{2}{*}{ 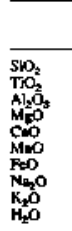 } & \multicolumn{2}{|c|}{${ }^{2 N \mathrm{H}} \mathrm{C}$} & \multicolumn{2}{|c|}{$\mathrm{R}^{2 \mathrm{MF}} \mathrm{C}$} & \multicolumn{2}{|c|}{$\mathrm{A}^{20 \mathrm{M} 1} \mathrm{C}$} & \multicolumn{2}{|c|}{$\mathrm{E}^{196 \mathrm{sin}} \mathrm{c}$} & ${ }_{n}^{\text {tomax }}$ & \multicolumn{2}{|c|}{ 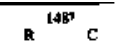 } \\
\hline & 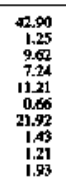 & 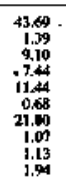 & 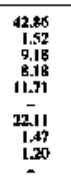 & 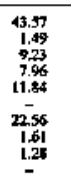 & 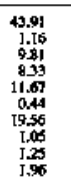 & 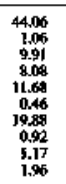 & 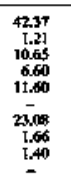 & 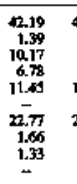 & 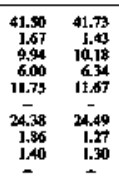 & 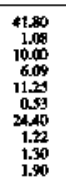 & 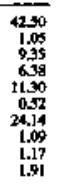 \\
\hline sLM & 99.97 & 99,65 & $98: 23$ & 99.4 & 90.4 & 9on & 98.57 & $9 n .74$ & \$2.50 80.41 & 99.60 & $90, \%$ \\
\hline Ptkbey) & 9.1 & 4.5 & 165 & 4.5 & 5.2 & $\$ .3$ & ti & 5.7 & $\begin{array}{ll}5.5 & 5.7\end{array}$ & 5.6 & 4.9 \\
\hline \multicolumn{12}{|c|}{ 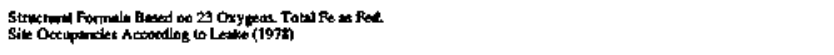 } \\
\hline$\$$ & 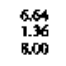 & $\begin{array}{l}6,7 \\
1,28 \\
1.00\end{array}$ & $\begin{array}{l}i_{14}^{58} \\
1.00 \\
8.00\end{array}$ & 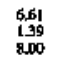 & $\begin{array}{l}6 \% 0 \\
1.00 \\
x, 00\end{array}$ & 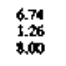 & $\begin{array}{l}\frac{6.54}{1.45} \\
1.42 \\
1800\end{array}$ & $\begin{array}{l}6,54 \\
1.46 \\
8000\end{array}$ & 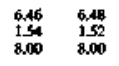 & $\begin{array}{l}654 \\
1.46 \\
1.400\end{array}$ & 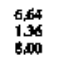 \\
\hline 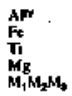 & 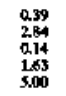 & $\begin{array}{l}0.37 \\
270 \\
0.16 \\
1.16 \\
5.00\end{array}$ & $\begin{array}{l}0.24 \\
3.84 \\
0.17 \\
0.17 \\
\text { s.7. } \\
\text { s.oil }\end{array}$ & $\begin{array}{l}0.25 \\
2.86 \\
0.17 \\
0.71 \\
\text { t.71 }\end{array}$ & $\begin{array}{l}0.46 \\
2.50 \\
0.17 \\
1.49 \\
5.00\end{array}$ & $\begin{array}{l}\frac{0.52}{2.5} \\
0.12 \\
0.12 \\
1.62 \\
5.00\end{array}$ & 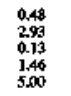 & 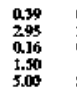 & 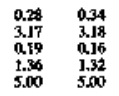 & 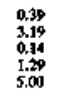 & $\begin{array}{l}0.36 \\
3.15 \\
0.12 \\
0.27 \\
1 ., 90\end{array}$ \\
\hline $\begin{array}{l}M_{B} \\
M_{B} \\
C \\
M_{u} \\
M_{4}\end{array}$ & 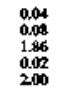 & $\begin{array}{l}2.03 \\
0.03 \\
1.83 \\
1.99 \\
1.99\end{array}$ & 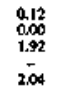 & $\begin{array}{l}\frac{0.06}{600} \\
1.92 \\
\overline{101}\end{array}$ & $\begin{array}{l}9,00 \\
0.00 \\
1.00 \\
0.09 \\
2.90\end{array}$ & $\begin{array}{l}\frac{0,02}{0.02} \\
0.09 \\
1.90 \\
0.09 \\
2.00\end{array}$ & 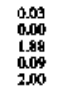 & $\begin{array}{l}0.06 \\
000 \\
1000 \\
000 \\
200 \\
200\end{array}$ & 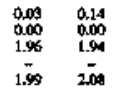 & $\begin{array}{l}9.3 \\
000 \\
1.80 \\
2.80\end{array}$ & $\begin{array}{l}0.11 \\
0,07 \\
1.99 \\
2,07\end{array}$ \\
\hline \multirow[t]{3}{*}{ 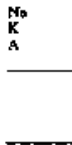 } & 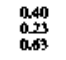 & $\begin{array}{l}\frac{0.32}{202} \\
0.25 \\
0.54\end{array}$ & $\begin{array}{l}0.43 \\
0.13 \\
0.66\end{array}$ & 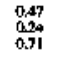 & sa & $\begin{array}{l}0.3 \\
0.97 \\
0.47 \\
0.47\end{array}$ & $\begin{array}{l}0.345 \\
0.27 \\
0.656\end{array}$ & $\begin{array}{l}0.43 \\
0,26 \\
071\end{array}$ & 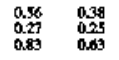 & $\begin{array}{l}039 \\
039 \\
0.62\end{array}$ & 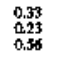 \\
\hline & \multicolumn{2}{|c|}{ [4tSMA' } & \multicolumn{2}{|c|}{ IAMMAM ' } & \multicolumn{2}{|c|}{199} & & \multirow{2}{*}{ 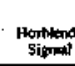 } & \multirow{2}{*}{ sibinin? } & & \\
\hline & $\mathrm{R}$ & c & R & c & R & c & Katkthe & & & & \\
\hline 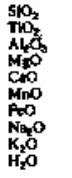 & 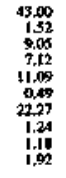 & 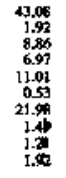 & 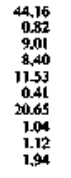 & 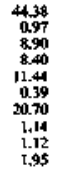 & 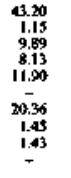 & 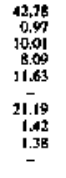 & 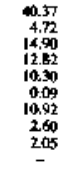 & 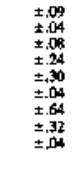 & $\begin{array}{c} \pm .95 \\
\pm .17 \\
\pm .77 \\
\pm=12 \\
\pm .20 \\
\pm .64 \\
\pm 10 \\
\pm 10 \\
\pm 10\end{array}$ & & \\
\hline sum & roso & ot & 9900 & 99.90 & 97.51 & 97.47 & 9.77 & & & & \\
\hline P(Rour) & 4.6 & 4 & 4,4 & $\$, 3$ & 3.3 & 53 & & & & & \\
\hline \multicolumn{12}{|c|}{ 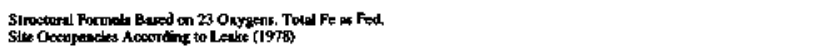 } \\
\hline $\begin{array}{l}\frac{5 n}{N^{m}} \\
T^{m}\end{array}$ & 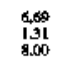 & $\begin{array}{l}0.070 \\
1.30 \\
8000\end{array}$ & $\begin{array}{l}6.727 \\
1.22 \\
8.00\end{array}$ & 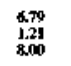 & 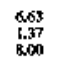 & $\begin{array}{l}6.50 \\
1.41 \\
8.00\end{array}$ & & & & & \\
\hline 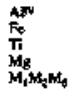 & 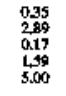 & 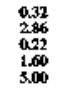 & $\begin{array}{l}0.144 \\
2.45 \\
20.09 \\
1.04 \\
1.00 \\
3.00\end{array}$ & 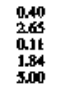 & $\begin{array}{l}\frac{0.41}{2.1} \\
2.61 \\
0.13 \\
1.50 \\
5.00\end{array}$ & 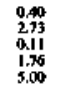 & & & & & \\
\hline 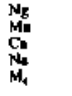 & 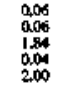 & 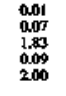 & $\begin{array}{l}0.07 \\
0.05 \\
1.09 \\
1091 \\
109\end{array}$ & $\begin{array}{l}0,07 \\
0,0 \% \\
1.87 \\
1.96\end{array}$ & $\begin{array}{l}0.00 \\
0.00 \\
1.95 \\
2.00\end{array}$ & $\begin{array}{l}8,09 \\
0.00 \\
1.92 \\
20.1\end{array}$ & & & & & \\
\hline${ }_{n}^{\text {sha }}$ & $\begin{array}{l}0.393 \\
0.93 \\
0.956\end{array}$ & 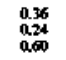 & $\begin{array}{l}0.30 \\
0.25 \\
0.51\end{array}$ & $\begin{array}{l}0133 \\
028 \\
0.54\end{array}$ & $\begin{array}{l}0.38 \\
\substack{0.28 \\
2 \times 6}\end{array}$ & $\begin{array}{l}0,4 i \\
0,77 \\
0,69\end{array}$ & & & & & \\
\hline
\end{tabular}


CONCLUSIONS The Itaporanga batholith shows whole rock intermediate $\delta^{18} \mathrm{O}$ values ranging from 8.8 permil to 10.4 permil (Tab. 1). The homogeneity of the oxygen isotope data througout the Itaporanga pluton, the low number of schist xenoliths which are only concentrated in the border zone, and the $\delta^{18} \mathrm{O}$ values from border to center of the pluton showing variation within 1 permu, rules out the possibility of country rock assimilation as a major process during its petrogenetic evolution.

Elsewhere, intermediate oxygen isotope values are sometimes caused by mingling and mixing of a magma produced by anatexis of metasedimentary rocks $\left(\delta^{18} \mathrm{O}>14\right.$ permil) with a mafic magma $\left(\delta^{18} \mathrm{O}<10\right.$ permil). However, a sample of potassium diorite collected in a pillow-like structure (20M, Tab. 1) which may represent, because of rapid cooling, the original isotopic ratio of the mafic magma, and a sample of the potassium diorite body (117DI, Tab. 1) collected east of the Itaporanga batholith are within \pm 1 permil of the Itaporanga rocks. This is a good evidence against such possibility.

Geobarometry based on Al content of calcic amphibole (ferroedenite to edenite, according to Leake 1978 classification), using the equation of Hollister et al. (1987), gave a crystallization pressure of 5 kbar \pm 1 kbar. Geothermometry based on oxygen isotope quartz-biotite pair, converted into the quartz-magnetite pair (Taylor 1968 and Shieh \& Schwarcz 1974) gave an average temperature of $558^{\circ} \mathrm{C}$, which probably represents subsolidus equilibrium (Tab. 2). Combining these data a geothermal gradient of approximately $30^{\circ} \mathrm{C} / \mathrm{km}$ is suggested for the area nearby the
Itaporanga pluton during its final emplacement.

The results of microprobe analyses of calcic amphibole evidences that the potassium diorite mafic enclaves failed to reequilibrate with the felsic porphyritic magma and have chemical compositions identical to the amphibole of the potassium diorite stock east of the Itaporanga pluton. This suggests a common origin for both.

The mafic enclaves sometimes with higher $\delta^{18} \mathrm{O}$ than the felsic porphyritic rocks, evidence that their oxygen isotope signatures reflect only their source and not interaction with the felsic magma.

The intensity of mechanical and chemical interaction between the two magmas (mushes) at the root zone of a diapir may have played a critical role for the oxygen isotope homogeneity of the pluton.

Acknowledgments $\mathrm{We}$ are grateful to FINEP/PADCT, for financial support. Thanks also go to CNPq and CAPES which provided one of us (GM) with scholarships for graduate studies at the University of Georgia, USA. The oxygen isotope analyses were performed at the University of Georgia, in the oxygen isotope laboratory under the directon of Dr. David B. Wenner to whom we express our'gratitude. This work is a portion of a $\mathrm{Ph}$. P. dissertation of one us (GM), presented at the University of Georgia. During the several phases of this work the facilities of the University of Georgia, and the Center for Granite Studies (NEG) in the Universidade Federal de Pernambuco, Brazil, were used.

\section{REFERENCES}

ANDERSON, A. T. JR.; CLAYTON, R. N.; MAYEDA T. K. 1971. Oxygen isotope thermometry of mafic igneous rocks. J. Geol., 79:715-729.

BOTTINGA, N. \& JAVOY, M. 1973. Comments on oxygen isotope geothermometry. Earth Planetary Science Letters, 20:250-265

DEINES, R. 1977. On the oxygen isotope distribution among triplets in igneous and metamorphic rocks. Geoch. Cosmoch. Acta, 41:1709-1730.

GILETTI, B. J. 1986. Diffusion effects on oxygen isotopes temperatures of slowly cooled igneous and metamorphic rocks. Earth Planetary Science Letters, 77:218-222.

HAMMARSTROM, J. M. \& ZEN, E. 1983. Possible use of Al content in hornblende as a geobarometer for plutonic rocks. Geol. Soc. Amer. Abstracts with Programs, 15:590.

HAMMARSTROM, J. M. \& ZEN, E. 1985. An empirical equation for igneous calcic amphibole geobarometry. Geol. Soc. Amer. Abstracts with Programs, 17:602

HAMMARSTROM, J. M. \& ZEN, E. 1986. Aluminum in hornblende: an empirical igneous geobarometer. Amer. Mineral., 72:1297-1313.

HOLLISTER, L. S.; GRISSOM, G. C.; FETTERS, E. K.; STOWELL, H. H.; SISSON, V. P. 1987. Confirmation of the empirical correlation of aluminum in hornblende with pressure of solidification of calc-alkaline plutons. Amer. Mineral., 72:213-239.

JAMES, D. E. 1981. The combined use of oxygen and radiogenic isotopes as indicators of crustal contamination. Annual Review Earth Planetary Science, 9:311 -320.

JAMES, D. E. 1982. A combined $\mathrm{O}, \mathrm{Sr}, \mathrm{Nd}$, and $\mathrm{Pb}$ isotopic and trace element study of crustal contamination in central Andean lavas: local geochemical variations. Earth Planetary Science Letters, 57:47-62.

LEAKE B. E. 1978. Nomenclature of amphibole. Amer. Mineral., 63:1023-1052.

MARIANO, G. 1989. Magma mixing origin of potassic cak-aDcaline pluton: the Itaporanga bathoKth, State of Paraiba, Northeastern Brazil. Athens. 180p. (Ph. D. dissertation, University of Georgia).

MASI, U.; O'NEIL, J. R.; KISTHER, R. W. 1981. Stable isotope systematic» in mesozoic granites of central and northern California and southwestern Oregon. Contrib. Mineral. Petrol., 76:116-126.

O'NEIL, J. R.; SHAW, S. E.; FLOOD, R. H. 1977 Oxygen and hydrogen as indicators of granite genesis in the New England batholith, Australia. Contrib. Mineral. Petrol., 62:313-328.
SHIEH, YUCH-NING \& SCHWARCZ, H. P. 1974. Oxygen isotope studies of granite and migmatite. Grenville province of Ontario, Canada. Geoch. Cosmoch. Acta. 38:21-45.

SIAL, A. N. 1984. Padrão regional de isotopes de oxigênio em granittfides do espaço Cachoeirinha, Nordeste do Brazil. In: CONGR. BRAS. GEOL., 33, Rio de Janeiro, 1984. Anais... Rio de Janeiro, SBG. v. 2, p. 2679-2697.

SIAL, A. N. 1986. Granite types in northeast Brasil: Current knowledge. Rev. Bras. Geoc., 16(1):54-72.

SILVA FILHO, M. A. 1985. Projeto Cachoeirinha. Recife, DNPM/CPRM. v.l, $128 \mathrm{p}$.

TAYLOR, H. P. JR. 1968. The oxygen isotope geochemistry of igneous rocks Contrib. Mineral Petrol 19:1 -17.

TAYLOR, H. P. JR. 1971. Oxygen isotope evidence for large scale interaction between meteoric water, ground waters, and Terciary granodiorite intrusions, western Cascades range Oregon. J Geophysical Research, 76:7855-7874.

TAYLOR, H. P. JR. 1980. The effects of assimilation of country rock by magmas on ${ }^{18} \mathrm{O} /{ }^{16} \mathrm{O}$ and ${ }^{87} \mathrm{Sr} /{ }^{86} \mathrm{Sr}$ systematics in igneous rocks. Earth Planetary Science Letters, 47:243-254.

TAYLOR, H. P. JR \& FORESTER, W. 1979. An oxygen isotope and hydrogen study of the Skaegaard intrusion and its country rocks: a description of a $55 \mathrm{~m}$.y. old fossil hydrothermal system. J. Petrol. 20:355-419.

TAYLOR, H. P. JR. \& EPSTEIN, S. 1962a. Relationship between $18 Q / 16 Q$ ratios in coexisting minerals of igneous and metamorphic rocks, parts 1,2. Geol. Soc. Amer, Bull., 73:461-480.

TAYLOR. H. P. JR. \& EPSTEIN, S. 1962b. Relationship between $18 \mathrm{Q} / 16 \mathrm{O}$ ratios in coexisting minerals of igneous and metamorphic rocks, parts 1,2. Geol. Soc. Amer. Butt., 73:675-694.

WENNER, D. B. 1981. Oxygen isotopic composition of the late erogenic granites in the southern Piedmont of the Appalachian Mountains, U.S.A and their relationship to subcrustal structures and lithologies.Eartft Planetary Science Letters, 54:186-199.

MANUSCRITO A605

Recebido em 16 de junho de 1989 Revisão do autor em 5 de fevereiro de 1990 Revisão aceita em 13 de fevereiro de 1990 